\title{
Seal Bomb Noise as a Potential Threat to Monterey Bay Harbor Porpoise
}

\begin{abstract}
Anne E. Simonis ${ }^{1,2 *}$, Karin A. Forney 2,3 , Shannon Rankin'2, John Ryan ${ }^{4}$, Yanwu Zhang ${ }^{4}$, Andrew DeVogelaere ${ }^{5}$, John Joseph ${ }^{6}$, Tetyana Margolina ${ }^{6}$, Anna Krumpel ${ }^{7,8}$ and Simone Baumann-Pickering ${ }^{7}$

${ }^{1}$ Ocean Associates, Inc., Arlington, VA, United States, ${ }^{2}$ Marine Mammal and Turtle Division, Southwest Fisheries Science Center, National Marine Fisheries, National Oceanic and Atmospheric Administration, La Jolla, CA, United States, ${ }^{3}$ Moss Landing Marine Laboratories, San Jose State University, Moss Landing, CA, United States, ${ }^{4}$ Monterey Bay Aquarium Research Institute, Moss Landing, CA, United States, ${ }^{5}$ Monterey Bay National Marine Sanctuary, National Ocean Service, National Oceanic and Atmospheric Administration, Monterey, CA, United States, ${ }^{6}$ Department of Oceanography, Naval Postgraduate School, Monterey, CA, United States, ${ }^{7}$ Acoustic Ecology Laboratory, Scripps Institution of Oceanography, University of California, San Diego, La Jolla, CA, United States, ${ }^{8}$ Department of Animal Physiology, University of Tuebingen, Tuebingen, Germany
\end{abstract}

OPEN ACCESS

Edited by:

Rebecca Dunlop,

The University of Queensland, Australia

Reviewed by: Danuta Maria Wisniewska, Centre National de la Recherche Scientifique (CNRS), France

Paul Wensveen,

University of Iceland, Iceland

*Correspondence: Anne E. Simonis anne.simonis@noaa.gov

Specialty section: This article was submitted to

Marine Megafauna, a section of the journal Frontiers in Marine Science

Received: 18 October 2019 Accepted: 24 February 2020

Published: 13 March 2020

Citation: Simonis AE, Forney KA, Rankin S, Ryan J, Zhang Y, DeVogelaere A, Joseph J, Margolina T, Krumpel A and Baumann-Pickering S (2020) Seal Bomb Noise as a Potential Threat to Monterey Bay Harbor Porpoise. Front. Mar. Sci. 7:142. doi: 10.3389/fmars.2020.00142
Anthropogenic noise is a known threat to marine mammals. Decades of research have shown that harbor porpoises are particularly sensitive to anthropogenic noise, and geographic displacement is a common impact from noise exposure. Small, localized populations may be particularly vulnerable to impacts associated with displacement, as animals that are excluded from their primary habitat may have reduced foraging success and survival, or be exposed to increased threats of predation or bycatch. Seal bombs are underwater explosives used in purse seine fisheries to deter marine mammals during fishery operations. Pinnipeds are believed to be the primary target for seal bomb use, however there may be indirect impacts on harbor porpoises. Active purse seine fishing using seal bombs in the greater Monterey Bay area may, at times, span the entire range of the Monterey Bay harbor porpoise stock, which may lead to negative impacts for this population. In this contribution, we review anthropogenic noise as a threat to harbor porpoises, with a focus on the potential for impacts from seal bomb noise exposure in the Monterey Bay region.

Keywords: harbor porpoise, seal bombs, noise, acoustic deterrents, fishery interactions, displacement, Monterey Bay

\section{ANTHROPOGENIC NOISE AS A THREAT}

Anthropogenic noise has been recognized as a threat to marine mammals for decades, making it a central issue for their conservation and management (Tougaard et al., 2015; National Marine Fisheries Service, 2016; Southall et al., 2019). For many marine mammals, hearing is the primary sensory modality, important for navigation, foraging, predator avoidance, and communication (Tyack, 1986). Noise can be considered as any sound that has the potential to interfere with normal functioning of auditory processes or cause harmful behavioral or physiological responses. Potential impacts of noise include interruption of essential behaviors (Wisniewska et al., 2018), masking 

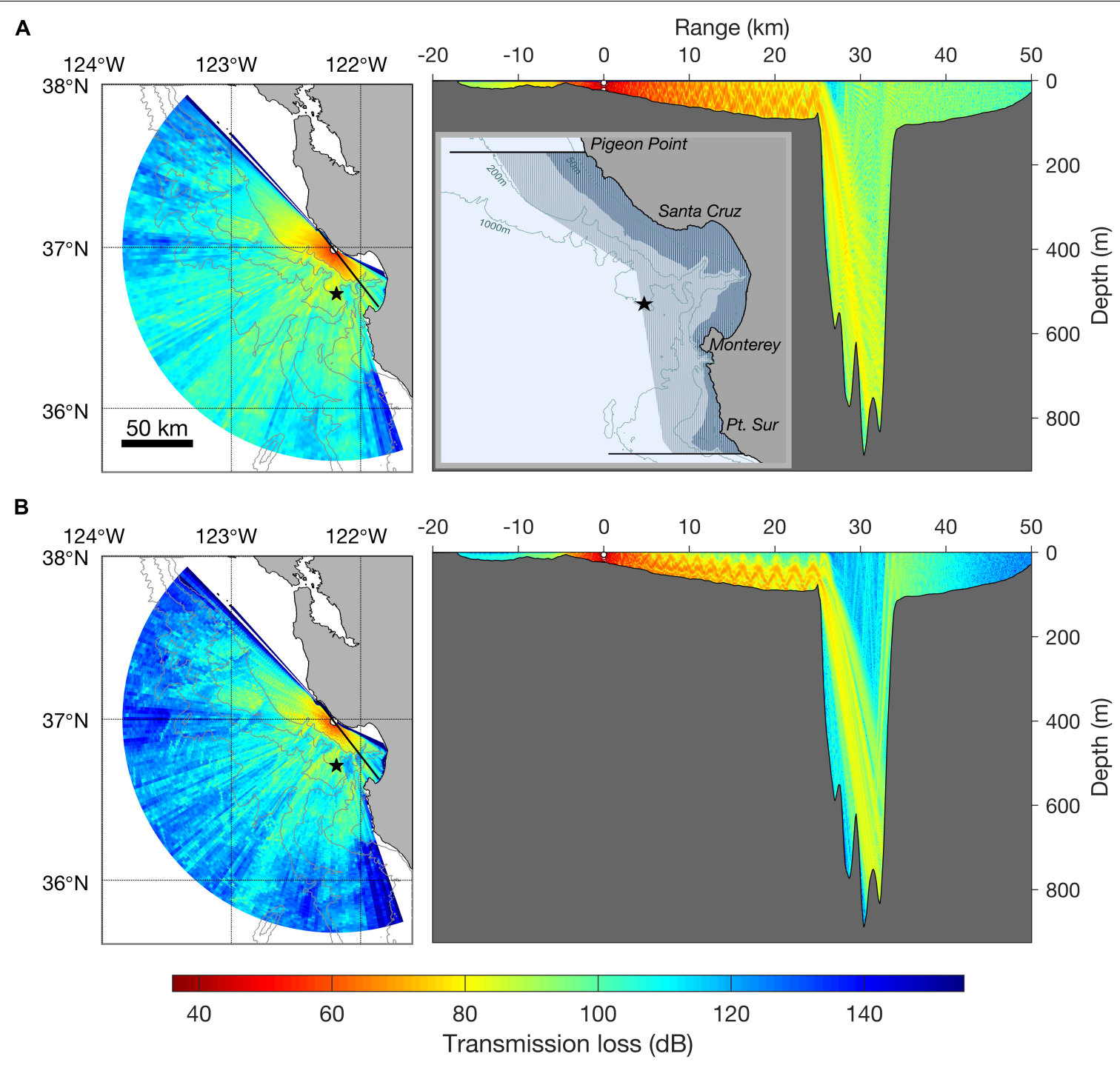

FIGURE 1 | Transmission loss model at $250 \mathrm{~Hz}$ (A) and $1000 \mathrm{~Hz}$ (B) for a seal bomb explosion ( $3 \mathrm{~m}$ depth, $36^{\circ} 59^{\prime} 6.20^{\prime \prime} \mathrm{N}, 122^{\circ} 11^{\prime} 44.53^{\prime \prime} \mathrm{W}$, average August sound speed profile). Isobaths are 200, 1000, 2000, and $3000 \mathrm{~m}$. Color indicates transmission loss at $20 \mathrm{~m}$ depth (left) and at all depths (right). Black star shows position of Monterey Accelerated Research System (MARS) cabled observatory (891 m), active since 2015, and where seal bombs have been acoustically detected. The right vertical profile shows the transmission loss model along a transect line (bearing $322^{\circ}$ and $142^{\circ}$ from the source; transect is shown by black thick line in horizontal range map). The inset map (top right) shows the distribution of the Monterey Bay harbor porpoise stock (black horizontal lines show recognized stock boundaries). Darker blue shading is primary habitat $[<50$ fathoms $=92 \mathrm{~m}]$ and medium blue shading shows the offshore extent of stock range. Isobaths in range map are 50 , 200, and $1000 \mathrm{~m}$.

signals of interest (e.g., the sounds of predators, conspecifics or prey) (Hermannsen et al., 2014), displacement from crucial habitat (Carstensen et al., 2006), direct physical injury including temporary or permanent hearing loss (Ketten et al., 2004; Finneran, 2015), and in extreme cases, death (Filadelfo et al., 2009). Strategies to mitigate noise impacts act to allow animals to avoid a noise source; however, there is growing concern that interruption of important behavior or displacement from crucial habitat may pose serious, population-level threats (Nowacek et al., 2007; Nabe-Nielsen et al., 2014, 2018; Forney et al., 2017).

Noise impacts may be particularly severe for small populations of acoustically sensitive marine mammals such as the harbor porpoise (Phocoena phocoena). Along the United States west coast, five populations ("stocks") of harbor porpoises are currently recognized under the Marine Mammal Protection Act, including the "Monterey Bay Stock" (Figure 1; Carretta et al., 2019) which ranges from just south of Point Sur to Pigeon Point, California. This is also a valuable region for squid and anchovy fisheries (California Department of Fish and Wildlife, 2019), which commonly use explosives called "seal bombs" to deter pinnipeds from catch or gear. Hence, there may be potential indirect impacts to harbor porpoises. In this review, we focus on the Monterey Bay harbor porpoise stock to evaluate potential impacts of seal bomb use in local fisheries and to 
identify assessment needs with respect to noise exposure from these explosives.

\section{HARBOR PORPOISE RESPONSE TO NOISE}

Throughout their global distribution, harbor porpoises are known to be particularly sensitive to acoustic disturbance. The range of best hearing for harbor porpoises extends from 4 to $150 \mathrm{kHz}$, making them members of a "Very HighFrequency (VHF)" hearing group (Kastelein et al., 2010; Southall et al., 2019). They use narrow-band high-frequency echolocation signals for navigation, foraging and communication (Verfuß et al., 2009; Clausen et al., 2011). Harbor porpoises and other VHF species have a relatively stiff basilar membrane (Ketten, 2000); this, along with metabolic processes in the inner ear, may lead to lower thresholds for hearing loss in porpoises compared to other odontocetes (Lucke et al., 2009; Southall et al., 2019). Beyond hearing loss, harbor porpoises are highly responsive to noise, and numerous studies have documented short and long-term displacements at various spatial scales (10s of $\mathrm{m}$ to $10 \mathrm{~s}$ of $\mathrm{km}$ ) when porpoises are exposed to diverse sounds including pile-driving (Tougaard et al., 2009), seismic surveys (Thompson et al., 2013), ship noise (Dyndo et al., 2015; Wisniewska et al., 2018), acoustic warning devices ("pingers") placed on fishing nets (Carlström et al., 2009), and nonexplosive acoustic harassment devices originally designed to deter pinnipeds (Brandt et al., 2013). Displacement from important habitat can be especially risky for small, localized populations of harbor porpoises, due to the increased stress, reduced foraging success and potential follow-on impacts to their survival and reproduction (Forney et al., 2017).

\section{EASTERN PACIFIC HARBOR PORPOISE DISTRIBUTION AND LIFE HISTORY}

Along the west coast of North America, harbor porpoises inhabit temperate, nearshore habitats from Point Conception, California $\left(34^{\circ} 33^{\prime} \mathrm{N}, 120^{\circ} 39^{\prime} \mathrm{W}\right)$ to Alaska, although fine-scale population structure has been identified through pollutant ratio studies (Calambokidis and Barlow, 1991) and genetic analyses (Chivers et al., 2002, 2007). The limited distribution, nonmigratory nature, and small population size of some of these stocks (e.g., Morro Bay, Monterey Bay) make them particularly vulnerable to localized impacts (Forney et al., 2014, 2017). The range of the Monterey Bay harbor porpoise population is primarily confined to water depths less than $200 \mathrm{~m}$ (less than $30 \mathrm{~km}$ offshore), and extends $100 \mathrm{~km}$ from north to south (Forney et al., 2014). Limited information is available on the life history of Monterey Bay harbor porpoises, but they are known to calve during late spring and early summer (MayJune; Sekiguchi, 1987). Their diet is seasonally variable, largely consisting of anchovies during spring through fall months, and market squid in winter months (Dorfman, 1990). From 1969 to 2002, the major threat to the Monterey Bay harbor porpoise population was bycatch in coastal set gillnet fisheries; a ban on gillnets inshore of 60 fathoms in this region eliminated this threat in 2002 (Barlow and Forney, 1994; Forney et al., 2001, 2014; Carretta et al., 2019). Recently, noise exposure associated with explosive acoustic deterrents used in fisheries has been recognized as a potential threat to cetaceans off California (Wiggins et al., 2019).

\section{SEAL BOMBS IN UNITED STATES WEST COAST FISHERIES}

Seal bombs are hand-thrown pyrotechnic devices designed to explode underwater to deter marine mammals during fishery operations. The underwater explosion of a seal bomb with $2.33 \mathrm{~g}$ of flash powder has an estimated zero-to-peak source level (SL) of $234 \mathrm{~dB}$ re $1 \mu \mathrm{Pa}$ at $1 \mathrm{~m}$, and estimated source sound exposure level (SEL) of $203 \mathrm{~dB}$ re $1 \mu \mathrm{Pa}^{2}$ s at $1 \mathrm{~m}$ when integrated over a 100 -ms time window, which approximates the integration time of mammalian ears and includes multiple bubble pulses associated with underwater explosions (Madsen, 2005; Tougaard et al., 2015; Wiggins et al., 2019). The frequency content of seal bomb explosions has not been reported in peer-reviewed literature, but examples show broadband energy reaching above $10 \mathrm{kHz}$, and the majority below $2 \mathrm{kHz}$ (Awbrey and Thomas, 1986; Ryan et al., 2016; Meyer-Loebbecke et al., 2017). Seal bomb impulse pressure is estimated at $208 \mathrm{~Pa} \mathrm{~s}$, but different manufacturers of seal bombs may use varying amounts (2-6 g) of flash powder which will affect the peak pressure of the explosion (Wiggins et al., 2019). The variation in the composition of seal bombs used in United States West coast fisheries is not known. The described seal bomb explosions may rise above background noise over distances of $10 \mathrm{~s}$ of $\mathrm{km}$; however, the environment (i.e., temperature profile, bathymetry) has a significant effect on sound propagation (Wiggins et al., 2019).

The primary concerns associated with the use of seal bombs include physical injuries estimated for close ranges $(<4 \mathrm{~m}$; Myrick et al., 1990), and auditory injuries and behavioral disturbances at longer ranges (Finneran, 2015; Wiggins et al., 2019). Smaller species of marine mammals are at greater risk for blast injuries (Ketten et al., 2004), and evidence of traumatic injuries to California sea lions (Zalophus californianus) from intra-oral explosions has been documented (Kerr and Scorse, 2018). Further, reports of dead fish in the vicinity of seal bomb explosions indicate various taxa may be at risk (National Marine Fisheries Service, 2008).

Research into the effectiveness of deterrents for pinnipeds is ongoing, but there have been few reports on the effectiveness of seal bombs. Multiple experiments have shown seal bombs as unreliable or ineffective deterrents for pinnipeds because animals eventually learn to tolerate the noise, however none of the published studies have been peer-reviewed (Geiger and Jeffries, 1986; Harvey and Mate, 1986; DeAngelis et al., 2008; Brown et al., 2009; Scordino, 2010). More research has been directed toward other acoustic deterrent devices, although there is considerable variation in the perceived effectiveness (Graham et al., 2009; Götz and Janik, 2013, 2015; Benjamins et al., 2018). When animals 


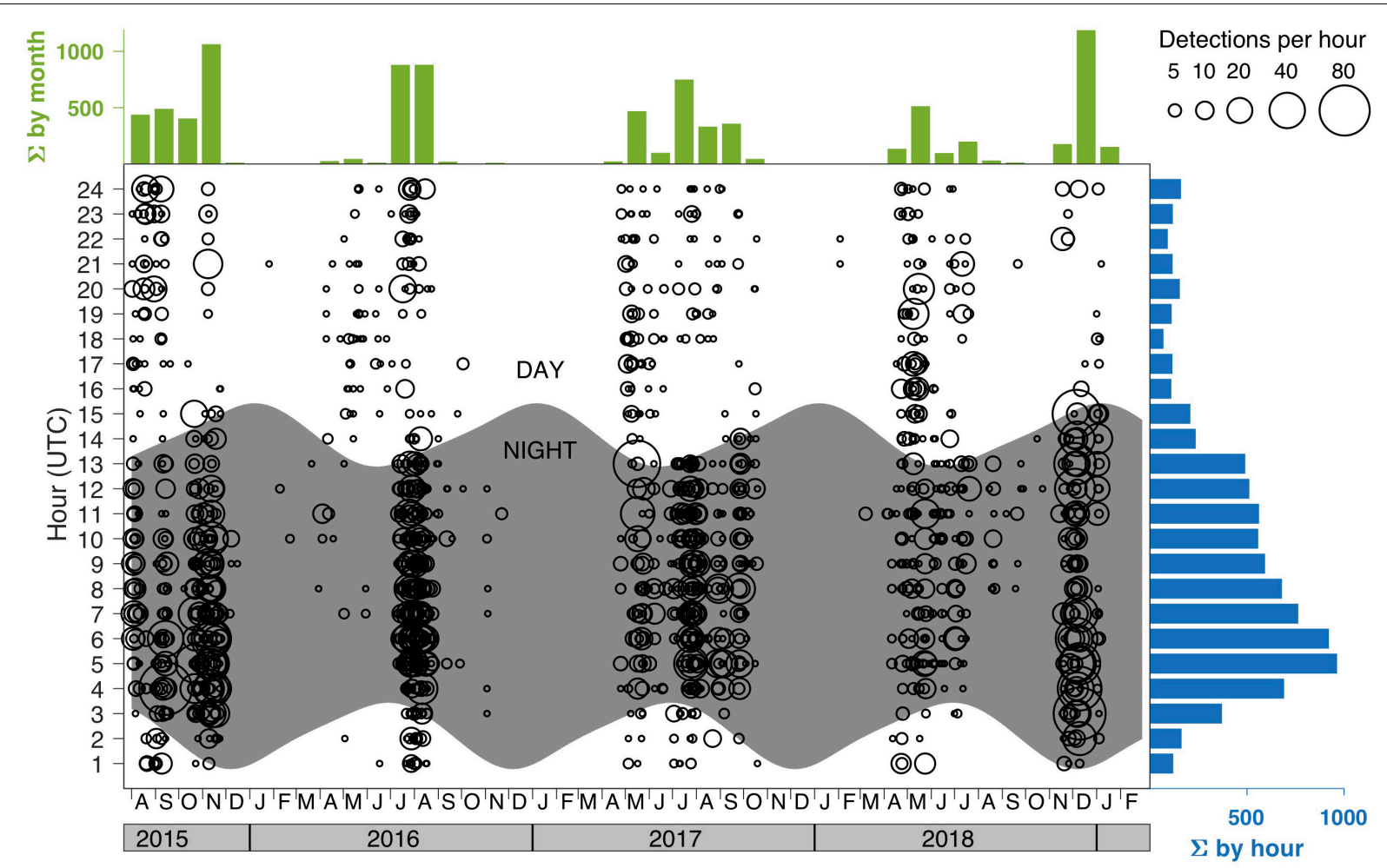

FIGURE 2 | True positive detections of seal bomb explosions in recordings from the MARS cabled observatory (https://www.mbari.org/at-sea/cabled-observatory/). Circle size represents the number of explosions per hour, for every hour of every day. Times are shown in UTC (Pacific Standard Time is UTC -8 h). Nighttime is shaded. Cumulative histograms are shown by hour and month. Figure reproduced with permission from Ryan (2019).

are strongly motivated by easily accessible, abundant, highquality food, habituation to deterrents commonly occurs and depredation will continue unless the animal's motivation can be satisfied by a suitable alternative (Schakner and Blumstein, 2013). However, with few clear options to address depredation, some United States west coast fisheries continue to use seal bombs to deter pinnipeds from their catch (Brown and Santoro, 2019), and may inadvertently be attracting pinnipeds through the "dinner bell effect" (Richardson et al., 2013).

Since 2005, seal bomb explosions have been documented at listening stations along the United States west coast, including Southern California (Meyer-Loebbecke et al., 2016), Monterey Bay (Ryan et al., 2016; Ryan, 2019), the Washington coast and Gulf of Alaska (Wiggins et al., 2017). Seal bomb use within Monterey Bay exhibits seasonal and diel patterns and can be pervasive at certain times, with up to 88 explosions per hour, 335 per day, and 1188 explosions per month (Figure 2) (Ryan, 2019). Monterey Bay has a complex bathymetry, with the continental shelf intersected by a deep submarine canyon. Simple models (e.g., spherical or cylindrical spreading) are not sufficient to estimate acoustic propagation here. We estimated the propagation from seal bomb noise using a physics-based propagation loss model as described in Margolina et al. (2018). Our transmission loss model (TL; Figure 1) is based on an explosion about 1 mile offshore of Davenport, CA $\left(36^{\circ} 59^{\prime} 6.20^{\prime \prime} \mathrm{N}, 122^{\circ} 11^{\prime} 44.53^{\prime \prime} \mathrm{W}\right)$ based on the source characterization in Wiggins et al. (2019), and an average sound speed profile for the month of August, when seal bomb detections were prevalent during 2015-2018 (Figure 2). Seal bomb explosion energy propagates throughout Monterey Bay (Figure 1) in an area of known importance to harbor porpoises (Calambokidis et al., 2015), exposing this restricted population to impacts associated with noise exposure.

\section{POTENTIAL IMPACTS ON HARBOR PORPOISE FROM SEAL BOMBS}

\section{Noise-Induced Threshold Shift}

Hearing loss from noise, also known as noise-induced threshold shifts (TS), can be temporary (TTS) or permanent (PTS), depending on the ability of the auditory system to recover once the sound has stopped. In marine mammal studies, TTS onset is usually defined as TS of $6 \mathrm{~dB}$ or greater measured shortly (1-4 min) after stopping the exposure (Southall et al., 2019). The short duration and high amplitude of impulsive sounds can create a greater risk of direct, mechanical (as opposed to metabolic) damage to the inner ear compared to non-impulsive sounds (Henderson and Hamernick, 1986). The repetition rate of a sound can also influence the magnitude of TTS when hearing does not recover completely within inter-pulse intervals (Finneran and Carder, 2010; Kastelein et al., 2014a). This means 
that while a single pulse may not induce TTS, the cumulative effects of repeated exposure may cause TTS. Ideally, the acoustic energy over time, including over multiple exposures (i.e., the cumulative SEL), along with the zero-to-peak SPL, should be used to determine noise exposure - see review in Southall et al. (2019). The onset of PTS in marine mammals has not been documented experimentally; however, based on studies on other mammals, zero-to-peak SPL and SEL criteria estimate PTS onset 6 and $15 \mathrm{~dB}$ above the respective TTS-onsets (Henderson and Hamernick, 1986; Southall et al., 2019).

For harbor porpoises, TTS onset has been measured for a variety of impulsive sound sources (Lucke et al., 2009; Kastelein et al., 2012, 2014b, 2015). Exposure limits for TTS at different frequencies show a similar shape to the porpoise audiogram, suggesting broadband SEL alone is not a good predictor for all frequencies and that frequency weighting is necessary to compare TTS thresholds of different sound sources (Tougaard et al., 2015). However, published records of VHF-weighted SELs of seal bombs are lacking. Among the stimuli studied for harbor porpoises, pile driving and seismic airguns are most similar to seal bombs due to their high-intensity, broadband impulses with strong lowfrequency components (Hermannsen et al., 2015; Kastelein et al., 2016). Thresholds for TTS and PTS in "Very High-Frequency" odontocetes including harbor porpoises, have been based on studies of these stimuli (Southall et al., 2019).

Using the TTS and PTS thresholds defined by Southall et al. (2019), and the TL model for Monterey Bay (Figure 1), we estimate that harbor porpoises may be exposed to noise levels that cause TTS and PTS at ranges out to 650 and $150 \mathrm{~m}$ from the explosion, respectively (Table 1). In our estimates, when considering zero-to-peak SPL thresholds, we use TL at $250 \mathrm{~Hz}$, as the bulk of energy in seal bomb noise is contained below this frequency (Awbrey and Thomas, 1986). When applying timeintegrated thresholds, such as SEL, we use TL at $1000 \mathrm{~Hz}$, because harbor porpoise hearing is more sensitive at higher frequencies (Kastelein et al., 2010). Neither TL model incorporates the time dispersion effects which will dissipate the peak energy of the waveform as it propagates (Urick, 1983), nor do they consider cumulative effects of multiple explosions or multiple sources.

Playback experiments using pile driving and airgun pulses show porpoise hearing loss at low frequencies (4 and $8 \mathrm{kHz}$; Kastelein et al., 2015, 2017), although experiments with tonal sounds show TTS at increasing frequencies above the exposure frequency as signal SPL increases (Kastelein et al., 2014a). It is unclear how TTS or PTS at low frequencies will impact the ultimate fitness of harbor porpoises, but impacts on their ability to forage, navigate and communicate will likely be negligible because there is no overlap with the high-frequency content of their echolocation clicks and communication signals (115$135 \mathrm{kHz}$; Clausen et al., 2011). However, whistles produced by North Pacific mammal-eating killer whales (Riesch and Deecke, 2011) fall directly in the range of observed harbor porpoise hearing loss from impulsive noise, which could impact their ability to detect potential predators.

The spatial distribution and rate of seal bomb explosions may be important contributing factors to the risk of noise-induced TS from cumulative sound exposure (Kastelein et al., 2016). Assuming the local TL model for seal bomb noise in Monterey Bay (Figure 1) and an equal energy model [i.e., TTS threshold of a cumulative SEL from multiple exposures is the same as a singlepulse TTS threshold - but see Kastelein et al. (2014a) regarding variation in TTS thresholds for different inter-pulse intervals], one can estimate that a porpoise would experience TTS from exposure to 2 explosions at $1 \mathrm{~km}$, or 6 explosions at $2 \mathrm{~km}$. To date the maximum seal bomb detection rate in Monterey Bay is 88 per hour (Ryan, 2019), which means a porpoise would have to remain within $2 \mathrm{~km}$ of the source for about $4 \mathrm{~min}$ to suffer TTS. In reality, porpoises will likely start moving away upon hearing

TABLE 1 | Estimated ranges of impacts from seal bomb noise exposure based on received level (RL) metrics reported in the literature and the seal bomb transmission loss (TL) model for Monterey Bay.

\begin{tabular}{|c|c|c|c|c|c|c|c|c|}
\hline & \multirow[b]{2}{*}{$\begin{array}{c}\text { RL } \\
\text { Metric }\end{array}$} & \multirow[b]{2}{*}{$\begin{array}{c}\text { Threshold or } \\
\text { Response Level }\end{array}$} & \multirow[b]{2}{*}{$\begin{array}{c}\text { Seal bomb SL } \\
\text { (at } 1 \mathrm{~m})\end{array}$} & \multicolumn{2}{|r|}{$250 \mathrm{~Hz}$} & \multicolumn{2}{|c|}{$1000 \mathrm{~Hz}$} & \multirow[b]{2}{*}{ References } \\
\hline & & & & $\begin{array}{c}\text { TL } \\
\text { (dB) }\end{array}$ & $\begin{array}{c}\text { Max distance } \\
\text { (km) }\end{array}$ & $\begin{array}{c}\text { TL } \\
\text { (dB) }\end{array}$ & $\begin{array}{c}\text { Max distance } \\
\text { (km) }\end{array}$ & \\
\hline \multirow[t]{2}{*}{ TTS } & $p_{0-p k}$ & $196 \mathrm{~dB}$ re $1 \mu \mathrm{Pa}$ & $234 \mathrm{~dB}$ re $1 \mu \mathrm{Pa}$ & 38 & 0.65 & & & Southall et al., 2019 \\
\hline & SEL & $164 \mathrm{~dB}$ re $1 \mu \mathrm{Pa}^{2} \mathrm{~s}$ & $203 \mathrm{~dB}$ re $1 \mu \mathrm{Pa}^{2} \mathrm{~s}$ & & & 39 & 0.3 & Lucke et al., 2009 \\
\hline PTS & $p_{0-p k}$ & $202 \mathrm{~dB}$ re $1 \mu \mathrm{Pa}$ & $234 \mathrm{~dB}$ re $1 \mu \mathrm{Pa}$ & 32 & 0.15 & & & Southall et al., 2019 \\
\hline \multirow[t]{6}{*}{ Avoidance } & SPLRMS & $145 \mathrm{~dB}$ re $1 \mu \mathrm{Pa}^{2}$ & $226 \mathrm{~dB}$ re $1 \mu \mathrm{Pa}$ & & & 81 & 118 & Bain and Williams, 2006 \\
\hline & SEL & $145-151 \mathrm{~dB}$ re $1 \mu \mathrm{Pa}^{2} \mathrm{~s}$ & $203 \mathrm{~dB}$ re $1 \mu \mathrm{Pa}^{2} \mathrm{~s}$ & & & $52-58$ & $2-9$ & Thompson et al., 2013 \\
\hline & $L_{\text {eq-fast }}{ }^{*}$ & $130 \mathrm{~dB}$ re $1 \mu \mathrm{Pa}$ & $210 \mathrm{~dB}$ re $1 \mu \mathrm{Pa}$ & & & 80 & 116 & Tougaard et al., 2015 \\
\hline & SEL & $139-152 \mathrm{~dB}$ re $1 \mu \mathrm{Pa}^{2} \mathrm{~s}$ & $203 \mathrm{~dB}$ re $1 \mu \mathrm{Pa}^{2} \mathrm{~s}$ & & & $51-64$ & $2-17$ & Dähne et al., 2013 \\
\hline & SEL & $143 \mathrm{~dB}$ re $1 \mu \mathrm{Pa}^{2} \mathrm{~s}$ & $203 \mathrm{~dB}$ re $1 \mu \mathrm{Pa}^{2} \mathrm{~s}$ & & & 60 & 11 & Brandt et al., 2018 \\
\hline & SEL & $130-158 \mathrm{~dB}$ re $1 \mu \mathrm{Pa}^{2} \mathrm{~s}$ & $203 \mathrm{~dB}$ re $1 \mu \mathrm{Pa}^{2} \mathrm{~s}$ & & & $45-73$ & $1-64$ & Sarnocińska et al., 2020 \\
\hline Reduced foraging & SEL & $130 \mathrm{~dB}$ re $1 \mu \mathrm{Pa}^{2} \mathrm{~s}$ & $203 \mathrm{~dB}$ re $1 \mu \mathrm{Pa}^{2} \mathrm{~s}$ & & & 73 & 64 & Pirotta et al., 2014 \\
\hline
\end{tabular}

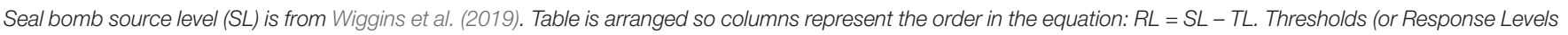

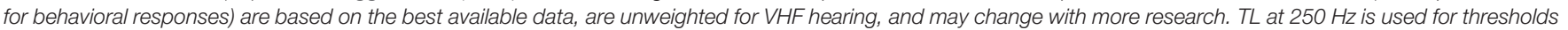

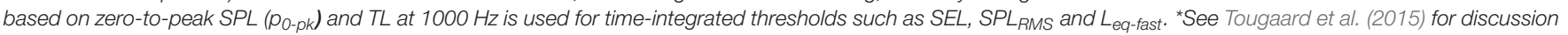
of $L_{\text {eq-fast }}$. 
the first impulse, and this movement can alter the risk for TTS (Aarts et al., 2016).

\section{Behavioral Response}

To date there have been no investigations into the response of harbor porpoises to seal bomb noise, however behavioral response studies on impulsive, low-frequency noise during pile driving associated with windfarm construction (Tougaard et al., 2009, 2015; Dähne et al., 2013; Graham et al., 2019), seismic airguns (Bain and Williams, 2006; Thompson et al., 2013), and other explosions (Von Benda-Beckmann et al., 2015) may provide valuable insight into response levels.

A variety of sound level metrics and behavioral response thresholds have been reported from studies of harbor porpoises exposed to low-frequency, impulsive stimuli (Table 1). While many authors report responses to airgun or pile driving noise at distances $>10 \mathrm{~km}$ (Bain and Williams, 2006; Carstensen et al., 2006; Tougaard et al., 2009; Dähne et al., 2013; Brandt et al., 2018; Sarnocińska et al., 2020), the environment will significantly impact sound propagation, so here we focus on estimating a maximum response distance based on reported received sound levels. As above, we use the TL model for Monterey Bay (Figure 1) to calculate the maximum ranges at which harbor porpoises could experience levels equal to the response thresholds reported in the literature when the sound source is a single seal bomb explosion. We estimate a potential range of disturbance up to $64 \mathrm{~km}$, but responses at ranges as long as $118 \mathrm{~km}$ cannot be excluded (Table 1). The maximum estimated range of response reported here does not consider scenarios of cumulative exposure to multiple explosions, or from multiple sources.

There is considerable variation in the estimated ranges over which Monterey Bay harbor porpoises will respond to seal bomb noise $(1-118 \mathrm{~km})$ based on studies of pile driving and airgun noise exposure (Table 1). However, considering the overlap of harbor porpoises with purse seine fisheries within Monterey Bay (California Department of Fish and Wildlife, 2019) and the expected seal bomb noise propagation, it is possible that harbor porpoises are exposed to noise from seal bomb explosions throughout much or all of their preferred habitat (Figure 1). The extent of impacts from noise-induced displacement will depend on displacement duration, quality of alternative habitat, and exposure to other risks such as predators or bycatch (Nabe-Nielsen et al., 2014, 2018).

Harbor porpoises have high-metabolic demands (Kastelein et al., 2018; Rojano-Doñate et al., 2018), so reduced foraging effort due to disturbance or displacement to suboptimal foraging areas for prolonged periods may have negative impacts on their ultimate fitness. Harbor porpoises have been shown to stop foraging due to noise exposure from shipping (Wisniewska et al., 2018) and seismic surveys (Pirotta et al., 2014), and even modest levels of anthropogenic disturbance may have severe consequences for their survival and reproduction if lost feeding opportunities cannot be energetically compensated for (Wisniewska et al., 2016).

Foraging success of harbor porpoises around Denmark is particularly critical in spring and summer to thicken blubber layers, which support high energy demands from pregnancy and cold temperatures during winter months (Kastelein et al., 2018). In Monterey Bay, harbor porpoises prey on seasonally abundant anchovy and market squid (Dorfman, 1990), thus seal bomb noise from both daytime (anchovy) and nighttime (squid) fishing may be detrimental to foraging success. With large interannual variation in seasonal timing, fishery explosion activity can be elevated between April and December (Figure 2), impacting spring-summer lactation and winter pregnancy periods. Recent bioenergetics-based models, which consider the species' life history and local habitat to assess population consequences of sub-lethal behavioral effects, can guide conservation and management strategies (Nabe-Nielsen et al., 2018).

\section{REDUCING IMPACTS}

The potential for injury and other negative impacts of seal bombs was a concern for dolphins in the Eastern Tropical Pacific tuna fishery in the 1980s until their use was outlawed in 1990 (Cassano et al., 1990; Myrick et al., 1990), but the impacts of seal bombs in other fisheries have not been discussed until recently (Götz and Janik, 2013; Meyer-Loebbecke et al., 2016; Ryan, 2019). The Monterey Bay National Marine Sanctuary advisory council has made formal recommendations to increase monitoring of sound over time, to catalog current uses of seal bombs, and to convene collaborative groups of diverse stakeholders with the goal of minimizing seal bomb use and developing effective alternative deterrents (Monterey Bay National Marine Sanctuary Advisory Council, 2017).

Under the Marine Mammal Protection Act, the National Marine Fisheries Service uses quantitative thresholds to consider multiple types of acoustic impacts including: PTS, TTS, and for explosives, direct injuries to lungs and gastrointestinal tracts (National Marine Fisheries Service, 2018). These quantitative thresholds may not encompass important behavioral responses, as there is growing evidence that the energetic costs associated with displacement can be detrimental to cetaceans, particularly for populations with high degrees of site fidelity (e.g., Bejder et al., 2009; Forney et al., 2017; Southall et al., 2019). In a 2015 workshop exploring non-lethal deterrents used in fisheries, there was general agreement that management strategies should be defined based on the most sensitive species in an area (Long et al., 2015). To the best of our knowledge, the most acoustically sensitive marine mammal species that resides year-round in Monterey Bay is the harbor porpoise.

Particularly within the Monterey Bay National Marine Sanctuary, it is imperative that potential harmful side effects of human activities are assessed and either shown to be benign, or modified to ensure other species are not negatively impacted. This is especially important for commercially valuable fisheries that support local communities. As we move toward ecosystembased management, there is a critical need for collaboration among fishermen, researchers and resource managers to develop, analyze, and implement strategies that protect the ecosystem while supporting the use of natural resources. 


\section{AUTHOR CONTRIBUTIONS}

AS, KF, SR, JR, JJ, and AD devised the initial plan for a minireview. TM ran the transmission loss model for a seal bomb explosion in local conditions of Monterey Bay. JR, YZ, AK, and SB-P contributed information on seal bomb detections along the US west coast. AS wrote the first draft of the manuscript. All authors contributed to manuscript revision, read and approved the submitted version.

\section{FUNDING}

Funding was provided by the NOAA Ocean Acoustics Program, the David and Lucile Packard Foundation through a grant to

\section{REFERENCES}

Aarts, G., Von Benda-Beckmann, S., Lucke, K., Sertlek, H. Ö, Van Bemmelen, R., Geelhoed, S. C. V., et al. (2016). Harbour porpoise movement strategy affects cumulative number of animals acoustically exposed to underwater explosions. Mar. Ecol. Prog. Ser. 557, 261-275. doi: 10.3354/meps 11829

Awbrey, F. T., and Thomas, J. A. (1986). "Measurement of sound propagation from several acoustic harassment devices," in Acoustic Deterrents in Marine Mammal Conflicts with Fisheries. A Workshop Held Feb 17-18, 1986, eds B. R. Mate, and J. T. Harvey (Newport, OR: Oregon Sea Grant), 85-104.

Bain, D. E., and Williams, R. (2006). "Long-range effects of airgun noise on marine mammals: responses as a function of received sound level and distance," in Proceeding of the 58th Annual Meeting of the International Whaling: IWCSC/58E35 (St Andrews: Sea Mammal Research Unit).

Barlow, J., and Forney, K. (1994). An Assessment of the 1994 Status of Harbor Porpoise in California. U.S. Department of Commerce, National Oceanic and Atmospheric Administration Technical Memorandum, NMFS-SWFSC-205, p. 17. La Jolla, CA: National Oceanic and Atmospheric Administration.

Bejder, L., Samuels, A., Whitehead, H., Finn, H., and Allen, S. (2009). Impact assessment research: use and misuse of habituation, sensitisation and tolerance in describing wildlife responses to anthropogenic stimuli. Mar. Ecol. Prog. Ser. 395, 177-185. doi: 10.3354/meps07979

Benjamins, S., Risch, D., Lepper, P., and Wilson, B. (2018). SARF112 - Influences of Lower-Frequency Acoustic Deterrent Devices (ADDs) on Cetaceans in Scottish Coastal Waters. A Study Commissioned by the Scottish Aquaculture Research Forum (SARF). Available online at: www.sarf.org.uk/ (accessed January 14, 2020).

Brandt, M. J., Dragon, A. C., Diederichs, A., Bellmann, M. A., Wahl, V., Piper, W., et al. (2018). Disturbance of harbour porpoises during construction of the first seven offshore wind farms in Germany. Mar. Ecol. Prog. Ser. 596, 213-232. doi: $10.3354 /$ meps 12560

Brandt, M. J., Höschle, C., Diederichs, A., Betke, K., Matuschek, R., and Nehls, G. (2013). Seal scarers as a tool to deter harbour porpoises from offshore construction sites. Mar. Ecol. Prog. Ser. 475, 291-302. doi: 10.3354/meps 10100

Brown, K., and Santoro, H. (2019). West Coast Fishermen Have Few Options Against Sea Lions. High Ctry. News. Available online at: https://www.hcn.org/issues/51.16/ocean-west-coast-fishermen-have-fewoptions-in-their-fight-against-sea-lions (accessed September 14, 2019).

Brown, R., Jeffries, S., Hatch, D., Wright, B., Jonker, S., and Whiteaker, J. (2009). Field Report: 2009 Pinniped Management Activities At and Below Bonneville Dam. Columbia River Inter-Tribal Fish Commission Report Reference \#09-10. Portland, OR: Columbia River Inter-Tribal Fish Commission.

Calambokidis, J., and Barlow, J. (1991). "Chlorinated hydrocarbon concentrations and their use for describing population discreteness in harbor porpoises from Washington, Oregon, and California," in Proceedings of the Second Marine Mammal Stranding Workshop: Marine Mammal Strandings in the United States,
Monterey Bay Aquarium Research Institute, and the Southwest Fisheries Science Center.

\section{ACKNOWLEDGMENTS}

We thank the numerous researchers who contributed in ways both minor and major to the efforts involved in collecting these passive acoustic recordings, conducting surveys to understand the distribution of harbor porpoise, and to the numerous institutions interested in reducing impact of sound on marine life, as well as finding a path forward to reduce depredation on fisheries by marine life. We would also like to thank the reviewers for their thoughtful comments and suggestions to improve the manuscript.

eds J. I. Reynolds, and D. Odell (Miami, FL: NOAA Technical Report NMFS 98), 101-110.

Calambokidis, J., Steiger, G. H., Curtice, C., Harrison, J., Ferguson, M. C., Becker, E., et al. (2015). Biologically important areas for selected cetaceans within U.S. waters - West Coast region. Aquat. Mamm. 41, 39-53. doi: 10.1578/AM.41.1. 2015.39

California Department of Fish and Wildlife, (2019). Landings Data Summaries and Maps. Pelagic Fisheries and Ecosystems Program. Monterey, CA: California Department of Fish and Wildlife.

Carlström, J., Berggren, P., and Tregenza, N. J. C. (2009). Spatial and temporal impact of pingers on porpoises. Can. J. Fish. Aquat. Sci. 66, 72-82. doi: 10.1139/ F08-186

Carretta, J. V., Forney, K., Oleson, E. M., Weller, D. W., Lang, A. R., Baker, J., et al. (2019). U.S. Pacific Marine Mammal Stock Assessments: 2018. NOAATM-NMFS-SWFSC-617. Silver Spring, MD: National Oceanic and Atmospheric Administration.

Carstensen, J., Henriksen, O. D., and Teilmann, J. (2006). Impacts of offshore wind farm construction on harbour porpoises: acoustic monitoring of echolocation activity using porpoise detectors (T-PODs). Mar. Ecol. Prog. Ser. 321, 295-308. doi: $10.3354 /$ meps 321295

Cassano, E. R., Albert, C., Myrick, J., Glick, C. B., Holland, R., and Lennert, C. (1990). The Use of Seal Bombs on Dolphin in the Yellowfin Tuna Purse-Seine Fishery. SWFC Administrative Report. La Jolla, CA: SWFC.

Chivers, S., Dizon, A., Gearin, P., and Robertson, K. (2002). Small-scale population structure of eastern North Pacific harbour porpoises (Phocoena phocoena) indicated by molecular genetic analyses. J. Cetacean Res. Manag. 4, 111-122.

Chivers, S., Hanson, B., Laake, J., Gearin, P., Muto, M., Calambokidis, J., et al. (2007). Additional Genetic Evidence for Population Structure of Phocoena phocoena, Off the Coasts of California, Oregon, and Washington. Administrative Report LJ-07-08. La Jolla, CA: U.S. Department of Commerce, National Oceanic and Atmospheric Administration.

Clausen, K. T., Wahlberg, M., Beedholm, K., Deruiter, S., and Madsen, P. T. (2011). Click communication in harbour porpoises Phocoena phocoena. Bioacoustics 20, 1-28. doi: 10.1080/09524622.2011.9753630

Dähne, M., Gilles, A., Lucke, K., Peschko, V., Adler, S., Krügel, K., et al. (2013). Effects of pile-driving on harbour porpoises (Phocoena phocoena) at the first offshore wind farm in Germany. Environ. Res. Lett 8, 16. doi: 10.1088/17489326/8/2/025002

DeAngelis, M. L., Hanan, D. A., and Curry, B. E. (2008). "Preliminary observations of the effectiveness of non-lethal deterrence methods for California sea lions and Pacific harbor seals along the coast of California," in Proceedings of the Vertebrate Pest Conference (Davis, CA: UC Agriculture \& Natural Resources).

Dorfman, E. J. (1990). Distribution, Behavior, and Food Habits of Harbor Porpoises (Phocoena phocoena) in Monterey Bay. MS thesis, San José State University, San Jose, CA, 57.

Dyndo, M., Wïnniewska, D. M., Rojano-Doñate, L., and Madsen, P. T. (2015). Harbour porpoises react to low levels of high frequency vessel noise. Sci. Rep. 5:1108. doi: 10.1038/srep 11083 
Filadelfo, R., Mintz, J., Michlovich, E., D’Amico, A., Tyack, P. L., and Ketten, D. R. (2009). Correlating military sonar use with beaked whale mass strandings: what do the historical data show? Aquat. Mamm. 35, 435-444. doi: 10.1578/AM.35. 4.2009 .435

Finneran, J. J. (2015). Noise-induced hearing loss in marine mammals: a review of temporary threshold shift studies from 1996 to 2015. J. Acoust. Soc. Am. 138, 1702-1726. doi: 10.1121/1.4927418

Finneran, J. J., and Carder, D. A. (2010). Temporary threshold shift in a bottlenose dolphin (Tursiops truncatus) exposed to intermittent tones. J. Acoust. Soc. Am. 127, 3267-3272. doi: 10.1121/1.3377052

Forney, K., Benson, S., and Cameron, G. (2001). "Central California gillnet effort and bycatch of sensitive species, 1990-1998," in Seabird Bycatch: Trends, Roadblocks, and Solutions, eds E. Melvin, and J. Parrish (Fairbanks, AK: University of Alaska Sea Grant), 141-160. doi: 10.4027/sbtrs.2001.08

Forney, K., Carretta, J., and Benson, S. (2014). Preliminary Estimates of Harbor Porpoise Abundance in Pacific Coast Waters of California, Oregon, and Washington 2007-2012. La Jolla, CA: National Oceanic and Atmospheric Administration.

Forney, K., Southall, B. L., Slooten, E., Dawson, S., Read, A. J., Baird, R. W., et al. (2017). Nowhere to go: noise impact assessments for marine mammal populations with high site fidelity. Endanger. Species Res. 32, 391-413. doi: 10.3354/esr00820

Geiger, A. C., and Jeffries, S. J. (1986). "Evaluation of seal harassment techniques to protect gill netted salmon," in Acoustic Deterrents in Marine Mammal Conflicts With Fisheries. A Workshop Held Feb 17-18, 1986. ORESU-W-86-001, eds B. R. Mate, and J. T. Harvey (Newport, OR: Oregon Sea Grant).

Götz, T., and Janik, V. M. (2013). Acoustic deterrent devices to prevent pinniped depredation: efficiency, conservation concerns and possible solutions. Mar. Ecol. Prog. Ser. 492, 285-302. doi: 10.3354/meps10482

Götz, T., and Janik, V. M. (2015). Target-specific acoustic predator deterrence in the marine environment. Anim. Conserv. 18, 102-111. doi: 10.1111/acv.12141

Graham, I. M., Harris, R. N., Denny, B., Fowden, D., and Pullan, D. (2009). Testing the effectiveness of an acoustic deterrent device for excluding seals from Atlantic salmon rivers in Scotland. ICES J. Mar. Sci. 66, 860-864. doi: 10.1093/icesjms/fsp111

Graham, I. M., Merchant, N. D., Farcas, A., Barton, T. R., Cheney, B., Bono, S., et al. (2019). Harbour porpoise responses to pile-driving diminish over time. R. Soc. Open Sci 6:190335. doi: 10.1098/rsos.190335

Harvey, J. T., and Mate, B. R. (1986). "The feasibility and effectiveness of using an acoustic barrier to restrict the movements of seals into Netarts Bay, Oregon," in Acoustic Deterrents in Marine Mammal Conflicts With Fisheries. A Workshop Held Feb 17-18, 1986. ORESU-W-86-001, eds B. R. Mate, and J. T. Harvey (Newport, OR: Oregon Sea Grant).

Henderson, D., and Hamernick, R. P. (1986). Impulse noise: critical review. J. Acoust. Soc. Am. 80, 569-584. doi: 10.1121/1.394052

Hermannsen, L., Beedholm, K., Tougaard, J., and Madsen, P. T. (2014). High frequency components of ship noise in shallow water with a discussion of implications for harbor porpoises (Phocoena phocoena). J. Acoust. Soc. Am. 136, 1640-1653. doi: 10.1121/1.4893908

Hermannsen, L., Tougaard, J., Beedholm, K., Nabe-Nielsen, J., and Madsen, P. T. (2015). Characteristics and propagation of airgun pulses in shallow water with implications for effects on small marine mammals. PLoS One 10, 1-17. doi: 10.1371/journal.pone.0133436

Kastelein, R. A., Gransier, R., Hoek, L., and Olthuis, J. (2012). Temporary threshold shifts and recovery in a harbor porpoise (Phocoena phocoena) after octave-band noise at $4 \mathrm{kHz}$. J. Acoust. Soc. Am. 132, 3525-3537. doi: 10.1121/1.4757641

Kastelein, R. A., Gransier, R., Marijt, M. A., and Hoek, L. (2015). Hearing frequency thresholds of harbor porpoises (Phocoena phocoena) temporarily affected by played back offshore pile driving sounds. J. Acoust. Soc. Am. 137, 556-564. doi: 10.1121/1.4906261

Kastelein, R. A., Helder-Hoek, L., Covi, J., and Gransier, R. (2016). Pile driving playback sounds and temporary threshold shift in harbor porpoises (Phocoena phocoena): effect of exposure duration. J. Acoust. Soc. Am. 139, 2842-2851. doi: 10.1121/1.4948571

Kastelein, R. A., Helder-hoek, L., and Jennings, N. (2018). Seasonal changes in food consumption, respiration rate, and body condition of a male harbor porpoise (Phocoena phocoena). Aquat. Mamm. 44, 76-91. doi: 10.1578/AM.44.1.2018.76
Kastelein, R. A., Helder-Hoek, L., Van de Voorde, S., von Benda-Beckmann, A. M., Lam, F.-P. A., Jansen, E., et al. (2017). Temporary hearing threshold shift in a harbor porpoise (Phocoena phocoena) after exposure to multiple airgun sounds. J. Acoust. Soc. Am. 142, 2430-2442. doi: 10.1121/1.5007720

Kastelein, R. A., Hoek, L., de Jong, C. A. F., and Wensveen, P. J. (2010). The effect of signal duration on the underwater detection thresholds of a harbor porpoise (Phocoena phocoena) for single frequency-modulated tonal signals between 0.25 and 160 kHz. J. Acoust. Soc. Am. 128, 3211-3222. doi: 10.1121/1.3493435

Kastelein, R. A., Hoek, L., Gransier, R., Rambags, M., and Claeys, N. (2014a). Effect of level, duration, and inter-pulse interval of $1-2 \mathrm{kHz}$ sonar signal exposures on harbor porpoise hearing. J. Acoust. Soc. Am. 136, 412-422. doi: 10.1121/1. 4883596

Kastelein, R. A., Schop, J., Gransier, R., and Hoek, L. (2014b). Frequency of greatest temporary hearing threshold shift in harbor porpoises (Phocoena phocoena) depends on the noise level. J. Acoust. Soc. Am. 136, 1410-1418. doi: 10.1121/ 1.4892794

Kerr, A., and Scorse, J. (2018). The Use of Seal Bombs in California Fisheries. Monterey, CA: Middlebury Institute of International Studies.

Ketten, D. R. (2000). "Cetacean Ears," in Hearing by Whales and Dolphins, eds. W. W. L. Au, R. R. Fay, and A. N. Popper (New York: Springer), 43-108. doi: 10.1007/978-1-4612-1150-1_2

Ketten, D. R., Scientist, S., Hole, W., Hole, W., and Unlimited, D. (2004). Experimental Measures of Blast and Acoustic Trauma in Marine Mammals, Final Report: N000149711030. Woods Hole, HA: Woods Hole Oceanographic Institution.

Long, K. J., DeAngelis, L., Engleby, L., Fauquier, D. A., Johnson, A. J., Kraus, S. D., et al. (2015). Marine Mammal Non-lethal Deterrents: Summary of the Technical Expert Workshop on Marine Mammal Non-Lethal Deterrents, 10-12 February 2015, Seattle, Washington. Seattle, WA: U.S. Department of Commerce, National Oceanic and Atmospheric Administration.

Lucke, K., Siebert, U., Lepper, P., and Blanchet, M. (2009). Temporary shift in masked hearing thresholds in a harbor porpoise (Phocoena phocoena) after exposure to seismic airgun stimuli. J. Acoust. Soc. Am. 125, 4060-4070. doi: $10.1121 / 1.3117443$

Madsen, P. T. (2005). Marine mammals and noise: problems with root mean square sound pressure levels for transients. J. Acoust. Soc. Am. 117:3952. doi: $10.1121 / 1.1921508$

Margolina, T., Joseph, J. E., and Southall, B. L. (2018). "BRS Sound Exposure Modeling Tool: a system for planning, visualization and analysis," in Proceedings of the IEEE/MTS Oceans Conference, Charleston, SC (Charleston, SC: IEEE).

Meyer-Loebbecke, A., Debich, A., Širović, A., Trickey, J., Roch, M., Caretta, J., et al. (2016). "Noise from explosive deterrents used by California fisheries and possible effects on marine life (poster)," in Proceedings of the 4th International Conference on the Effects of Noise on Aquatic Life, July 10-16, Dublin.

Meyer-Loebbecke, A., Fraiser, K., Simonis, A., Reese, F., Kim, E. B., Hildebrand, J. A., et al. (2017). "Squid as common target: do areas with fishery-related explosions and dolphin foraging habitats overlap? (poster)," in Proceedings of the 31st Annual Meeting of the European Cetacean Society, May 1-3, 2017, Middelfart.

Monterey Bay National Marine Sanctuary Advisory Council, (2017). Final Meeting Minutes June 16, 2017. Cambria, CA: Monterey Bay National Marine Sanctuary Advisory Council.

Myrick, A. C., Cassano, E. R., and Oliver, C. W. (1990). Potential for Physical Injury, Other Than Hearing Damage, to Dolphins From Seal Bombs Used in the Yellowfin Tuna Purse-Seine Fishery: Results From Open-Water Tests. Cambridge: Cambridge University Press.

Nabe-Nielsen, J., Sibly, R. M., Tougaard, J., Teilmann, J., and Sveegaard, S. (2014). Effects of noise and by-catch on a Danish harbour porpoise population. Ecol. Modell. 272, 242-251. doi: 10.1016/j.ecolmodel.2013.09.025

Nabe-Nielsen, J., van Beest, F. M., Grimm, V., Sibly, R. M., Teilmann, J., and Thompson, P. M. (2018). Predicting the impacts of anthropogenic disturbances on marine populations. Conserv. Lett. 11, 1-8. doi: 10.1111/conl. 12563

National Marine Fisheries Service, (2008). Environmental Assessment for the Take of California Sea Lions at Bonneville Dam Pursuant to Section 120 of the Marine Mammal Protection Act. Silver Spring, MD: National Marine Fisheries Service. 
National Marine Fisheries Service, (2016). Technical Guidance for Assessing the Effects of Anthropogenic Sound on Marine Mammal Hearing Underwater Acoustic Thresholds for Onset of Permanent and Temporary Threshold Shifts. Silver Spring, MD: National Marine Fisheries Service.

National Marine Fisheries Service, (2018). 2018 Revisions to: Technical Guidance for Assessing the Effects of Anthropogenic Sound on Marine Mammal Hearing (Version 2.0). NOAA Tech. Memo. NMFS-OPR-59, 167. Silver Spring, MD: National Marine Fisheries Service.

Nowacek, D. P., Thorne, L. H., Johnston, D. W., and Tyack, P. L. (2007). Responses of cetaceans to anthropogenic noise. Mamm. Rev. 37, 81-115. doi: 10.1111/j. 1365-2907.2007.00104.x

Pirotta, E., Brookes, K. L., Graham, I. M., and Thompson, P. M. (2014). Variation in harbour porpoise activity in response to seismic survey noise. Biol. Lett. 10:20131090. doi: 10.1098/rsbl.2013.1090

Richardson, W. J., Greene, C. R. Jr., Malme, C. I, and Thomson, D. H. (2013). Marine Mammals and Noise. London: Academic Press.

Riesch, R., and Deecke, V. B. (2011). Whistle communication in mammal-eating killer whales (Orcinus orca): further evidence for acoustic divergence between ecotypes. Behav. Ecol. Sociobiol. 65, 1377-1387. doi: 10.1007/s00265-011-1148-8

Rojano-Doñate, McDonald, B. I, Wisniewska, D. M. M., Johnson, M., Telimann, J., Wahlberg, M., et al. (2018). High field metabolic rates of wild harbour porpoises. J. Exp. Biol. 221:jeb185827. doi: 10.1242/jeb.185827

Ryan, J. (2019). Acoustic Monitoring in Monterey Bay National Marine Sanctuary through the Monterey Accelerated Research System (MARS). Moss Landing, CA: Monterey Bay National Marine Sanctuary.

Ryan, J., Cline, D., Dawe, C., McGill, P., Zhang, Y., Joseph, J., et al. (2016). "New passive acoustic monitoring in Monterey Bay National Marine Sanctuary: exploring natural and anthropogenic sounds in a deep soundscape," in OCEANS 2016 MTS (Monterey, CA: IEEE). doi: 10.1109/OCEANS.2016.7761363

Sarnocińska, J., Teilmann, J., Balle, J., van Beest, F., Delefosse, M., and Tougaard, J. (2020). Harbor porpoise (Phocoena phocoena) reaction to a 3D seismic airgun survey in the North Sea. Front. Mar. Sci. 6:824. doi: 10.3389/fmars.2019.00824

Schakner, Z. A., and Blumstein, D. T. (2013). Behavioral biology of marine mammal deterrents: a review and prospectus. Biol. Conserv. 167, 380-389. doi: 10.1016/j. biocon.2013.08.024

Scordino, J. (2010). West Coast Pinniped Program Investigations on California Sea Lion and Pacific Harbor Seal Impacts on Salmonids and Other Fishery Resources. Pacific States Marine Fisheries Commission. Silver Spring, MD: National Marine Fisheries Service.

Sekiguchi, K. (1987). Occurrence and Behavior of Harbor Porpoises (Phocoena phocoena) at Pajaro Dunes, Monterey Bay, California. Master thesis, San Jose State University, San Jose, CA.

Southall, B. L., Finneran, J. J., Reichmuth, C., Nachtigall, P. E., Ketten, D. R., Bowles, A. E., et al. (2019). Marine mammal noise exposure criteria: updated scientific recommendations for residual hearing effects. Aquat. Mamm. 45, 125-232. doi: 10.1578/AM.45.2.2019.125

Thompson, P. M., Brookes, K. L., Graham, I. M., Barton, T. R., Needham, K., Bradbury, G., et al. (2013). Short-term disturbance by a commercial twodimensional seismic survey does not lead to long-term displacement of harbour porpoises. Proc. R. Soc. B Biol. Sci. 280:20132001. doi: 10.1098/rspb.2013. 2001
Tougaard, J., Carstensen, J., Teilmann, J., Skov, H., and Rassmussen, P. (2009). Pile driving zone of responsiveness extends beyond $20 \mathrm{~km}$ for harbor porpoises (Phocoena phocoena). J. Acoust. Soc. Am. 126, 11-14. doi: 10.1121/1.31 32523

Tougaard, J., Wright, A. J., and Madsen, P. T. (2015). Cetacean noise criteria revisited in the light of proposed exposure limits for harbour porpoises. Mar. Pollut. Bull. 90, 196-208. doi: 10.1016/j.marpolbul.2014. 10.051

Tyack, P. L. (1986). Population biology, social behavior and communication in whales and dolphins. Trends Ecol. Evol. 1, 144-150. doi: 10.1016/0169-5347(86) 90042-X

Urick, R. J. (1983). Principles of Underwater Sound, 3rd Edn. New York: McGrawHill, Inc.

Verfuß, U. K., Miller, L. A., Pilz, P. K. D., and Schnitzler, H. (2009). Echolocation by two foraging harbour porpoises (Phocoena phocoena). J. Exp. Biol. 212, 823-834. doi: $10.1242 /$ jeb.022137

Von Benda-Beckmann, A. M., Aarts, G., Sertlek, H. Ö, Lucke, K., Verboom, W. C., Kastelein, R. A., et al. (2015). Assessing the impact of underwater clearance of unexploded ordnance on harbor porpoises (Phocoena phocoena) in the Southern North Sea. Aquat. Mamm. 41, 503-523. doi: 10.1578/am.41.4. 2015.503

Wiggins, S. M., Debich, A. J., Trickey, J. S., Rice, A. C., Thayre, B. J., Baumannpickering, S., et al. (2017). Summary of Ambient and Anthropogenic Sound in the Gulf of Alaska and Northwest Coast. Marine Physical Laboratory Technical Memorandum MPL TM-611. San Diego, CA: University of California San Diego.

Wiggins, S. M., Krumpel, A., Dorman, L., Hildebrand, J., and BaumannPickering, S. (2019). Seal Bomb Sound Source Characterization. MPL Technical Memorandum 633. La Jolla, CA: University of California San Diego.

Wisniewska, D. M. M., Johnson, M., Teilmann, J., Rojano-Doñate, L., Shearer, J., Sveegaard, S., et al. (2016). Ultra-high foraging rates of harbor porpoises make them vulnerable to anthropogenic disturbance. Curr. Biol. 26, 1441-1446. doi: 10.1016/j.cub.2016.03.069

Wisniewska, D. M. M., Johnson, M., Teilmann, J., Siebert, U., Galatius, A., Dietz, R., et al. (2018). High rates of vessel noise disrupt foraging in wild harbour porpoises (Phocoena phocoena). Proc. R. Soc. B Biol. Sci. 285:1872. doi: 10.1098/ rspb.2017.2314

Conflict of Interest: AS was employed by the company Ocean Associates, Inc.

The remaining authors declare that the research was conducted in the absence of any commercial or financial relationships that could be construed as a potential conflict of interest.

Copyright (c) 2020 Simonis, Forney, Rankin, Ryan, Zhang, DeVogelaere, Joseph, Margolina, Krumpel and Baumann-Pickering. This is an open-access article distributed under the terms of the Creative Commons Attribution License (CC BY). The use, distribution or reproduction in other forums is permitted, provided the original author(s) and the copyright owner(s) are credited and that the original publication in this journal is cited, in accordance with accepted academic practice. No use, distribution or reproduction is permitted which does not comply with these terms. 